\title{
Assessment of Environmental Quality, Degree of Optimism, and the Assignment of Responsibility Regarding the State of the Environment in Latin America*
}

\author{
Evaluación de la Calidad Ambiental, Grado de Optimismo \\ y Asignación de Responsabilidad con Respecto al \\ Estado del Ambiente en Latinoamérica
}

Recibido: marzo 8 de 2015 | Revisado: abril 15 de 2015 | Aceptado: mayo 15 de 2015

doi:10.11144/Javeriana.upsy14-2.aeqd

Para citar este artículo: Páramo, P., Sandoval.Escobar, M., Jakovcevic, A., Ferreiro, J., Mustaca, A., Jengich, A., ... Castillo, B. (2015). Assessment of environmental quality, degree of optimism, and the assignment of responsibility regarding the state of environment in Latin America. Universitas Psychologica, 14(2), 605-618. http://dx.doi.org.10.11144/ Javeriana.upsy14-2.aeqd

Original research article

*** Doctorado Interinstitucional en Educación, Universidad Pedagógica Nacional, Colombia

*** Doctorado Interinstitucional en Educación, Universidad Pedagógica Nacional, Colombia. Fundación Universitaria Konrad Lorenz, Colombia

****** Laboratorio de Psicología Experimental \& Aplicada (PSEA), Instituto de Investigaciones Médicas (IDIM-CONICET) - Universidad Abierta Interamericana Argentina

******* Laboratorio de Psicología Experimental \& Aplicada (PSEA), Instituto de Investigaciones Médicas (IDIM-CONICET) - Universidad Abierta Interamericana Argentina

******** Laboratorio de Psicología Experimental \& Aplicada (PSEA), Instituto de Investigaciones Médicas (IDIM-CONICET) - Universidad Abierta Interamericana Argentina

\author{
PABlo PÁrAmo** \\ Universidad Pedagógica Nacional, Colombia \\ MARITHZA SANDOVAL-EsCOBAR *** \\ Fundación Universitaria Konrad Lorenz, Colombia \\ ADRIANA JAKOVCEVIC ***** \\ Instituto de Investigaciones Médicas \\ JULIÁN FERREIRO ****** \\ Instituto de Investigaciones Médicas
}

AlbA MUSTACA ******

Instituto de Investigaciones Médicas

AleXA Jengich

Academia INEINA, CIDE Costa Rica

JOSÉ BRENES

RECIEM, Costa Rica

Patricia Ortega-Andeane

Universidad Nacional Autónoma de México

FABIOLA VIVAS

Universidad Nacional Experimental del Táchira, Venezuela

Oscar Moros

Universidad Nacional Experimental del Táchira, Venezuela

CARMEN MÉNDEZ

Universidad Nacional Experimental del Táchira, Venezuela

Carlota Pasquali

Universidad Simón Bolívar, Venezuela

Marlise Aparecida BASSANI

Pontificia Universidad de Sao Paulo, Brasil

José ANICAMA GÓMEZ

Universidad Autónoma de Perú

Betty Castillo

Universidad Autónoma de Perú

MARIANEla DeneGri

Universidad de la Frontera, Chile

Alfonso UrzúA

Universidad Católica de Chile, Chile 


\section{A B S T R A C T}

This study explores the assessments made by the inhabitants of eight Latin American countries regarding the current state of the environment, at a local, national and global scale, and how it is perceived looking ahead to the future. It also examines the assignment of responsibility in the future management of the environment. A total of 944 people took part in the study from the eight participating countries, men and women over the age of 18 with different levels of education. The study uses the Environmental Futures Scale to which two relevant items have been added to assess the environment in the region, as well as the Assignment of Environmental Responsibility Scale. The results show differences between the countries, although in general they are pessimistic regarding the current and future state of the environment at the local, national and global level, with the exception of Brazil. In general, and with the exception of Brazil, in the countries surveyed, people assign a high level of responsibility to external social agents at the different levels, increasing their judgement of external responsibility at the national and global levels of analysis. The implications of these findings for environmental policy and education in the countries of this region are also discussed.

Keywords

environmental optimism; cross-cultural; environmental education; environmental responsibility; Environmental Futures Scale;

Environmental Responsibility Scale

\section{RESUMEN}

El presente estudio explora las evaluaciones realizadas por los habitantes de ocho países de América Latina en relación con su percepción sobre el estado actual del medio ambiente a escala local, nacional y mundial, así como las expectativas hacia el futuro del ambiente y la asignación de responsabilidades en cuanto a la gestión del futuro ambiental. Participaron un total de 944 personas de ocho países, hombres y mujeres de más 18 años con diferentes niveles de educación. Se aplicó la Escala de Futuros Ambientales a la que se le añadieron dos ítems pertinentes para evaluar el medio ambiente en la región y los ítems correspondientes a la Escala de Responsabilidad Ambiental. Los resultados muestran diferencias entre los países, aunque en general son pesimistas sobre el estado actual y futuro del medio ambiente a nivel local, nacional y mundial, con la excepción de Brasil. Igualmente en general, y con la excepción de Brasil, en los diferentes países encuestados las personas asignan un alto nivel de responsabilidad a los agentes sociales externos en los diferentes niveles, siendo más grande la responsabilidad asignada en los ámbitos nacional y mundial. También se discuten las implicaciones de estos hallazgos para la política del medio ambiente y las implicaciones para la educación en los países de esta región.

Palabras clave

optimismo ambiental; estudios transculturales; educación ambiental; responsabilidad ambiental; Escala de Futuros

Ambientales; Escala de Responsabilidad Ambiental
In recent years, society has become more concerned about environmental problems, partly thanks to the agreements reached at the Río de Janeiro Summit in 1992, where commitments were set out to protect the world's natural resources, which were subsequently strengthened at various international summits and through the creation of institutions and public policies that, supported by political parties that have included environmental protection and working with environmental charities as part of their agenda, have made a significant contribution to raising levels of concern about the state of the Earth's environment. Consequently, environmental problems are now a key area of research in various disciplines, helping to further understanding of the issue and find solutions. Particularly, the field of Human Sciences has highlighted the responsibility of social and cultural systems regarding the majority of environmental problems, considering human behaviour to be a fundamental variable with regard to environmental protection when it comes to resolving these problems efficiently (Meadows, Meadows, \& Randers, 1992). Hence, for Psychology, studies into proenvironmental behaviour and environmental attitudes have increased significantly, representing as much as $25 \%$ of all publications featured in the two most important journals in this area: Environment and Behavior and Journal of Environmental Psychology (Giuliani \& Scopelliti, 2009). Many of these studies have focused on measuring attitudes, beliefs or behavioural intent towards the environment (Ajzen, 1991; Bamberg \& Moser, 2007; Corral-Verdugo, Garcia-Cadena, \& Frías-Armenta, 2010; Páramo \& Gómez, 1997).

The variables studied in relation to environmental attitudes have been linked with age (Klineberg, McKeever, \& Rothenbach, 1998), gender (Tikka, Kuitunen, \& Tynys, 2000), social status (Uyeki \& Holland, 2000), place of residence (rural or urban, Rauwald \& Moore, 2002), and the political and religious orientation of the participants in these studies (Schultz, 2000). For example, the study conducted by Howell \& Laska (1992) provides evidence that young people have more favourable attitudes towards the environment than older adults. With regard to gender, women display a greater level of 
awareness regarding environmental problems than men (Xiao \& Dunlap, 2007). People with a lower level of education and lower earnings display fewer attitudes aimed at environmental protection (Shen $\&$ Saijo, 2008). Individuals who live in large urban centres seem to display greater concern about environmental deterioration (Berenguer, Corraliza, \& Martín, 2005). Finally, regarding political orientation, liberals are seen to display a better attitude towards the environment than conservatives (Daneshvary, Daneshvary, \& Schwe, 1998). An extensive recent review of the studies associated with these variables can be found in the work of Gifford and Sussman (2012). However, as pointed out by Hernández, Hidalgo, Salazar-Laplace and Hess (2010), the conclusions drawn should be approached with caution, since many of these relationships are weak, and principally because attitudes can change over time. Furthermore, there are sometimes major variations between countries, as shown by Gifford et al. (2009), who applied the Environmental Futures Scale (EFS) to evaluate perceptions of current and future environmental quality at three levels - local, national and global - among people from 18 countries around the world, chiefly in Asia, Europe and North America. From Latin America, only Mexico and Brazil were represented. The study showed that the predominant vision regarding the state of the environment in the future was pessimistic, although differences were observed between the countries. In addition, the participants considered the state of the environment at the local level to be better in their respective countries than at a global level (Gifford et al., 2009).

More recently, Shultz et al. (2012) conducted a reanalyses of a large cross-cultural data set (22 countries and 3,277 individuals) and new cross-cultural data (8 countries and 1,131 individuals) examining the prevalence of this spatial bias in the rated severity of environmental problems along with analyses of individual and country-level predictors of this bias. Results confirmed that spatial bias was greater for happier and younger individuals and for those from smaller communities. They interpret these results as evidence for self-serving and "place-serving" biases in which the bias tempers the severity of environmental problems in one's local area. Considering the large cross-cultural evidence, they argue that spatial bias is a plausible candidate of a psychological universal identified by research in environmental psychology (p. 32).

This article is presented as an extension of the aforementioned work insofar as it adopts the EFS to explore the state of the environment as perceived by inhabitants of different countries in the region. Identifying these perceptions is important not only because so far no approaches have been developed to assess the vision of Latin Americans about the state of the environment at a local level, in their own countries and in general of the planet, nor their level of pessimism or optimism in relation to such matters, but also because to some extent it allows the different actions undertaken by governmental institutions and civil society to be evaluated with regard to levels of environmental awareness. In this same direction, knowing the degree of sensitivity (pessimism or optimism) to the environmental issue will allow us to predict the acceptance of new policies aimed at regulating the exploitation of natural resources in the region. Furthermore, evaluating which individuals or bodies are assigned responsibility for environmental protection by the Latin American population provides an additional important element to strengthen or redirect environmental education programmes. Although the concept of assignment refers to the evaluation made by individuals of their own behaviours (Heider, 1958; Rotter, 1954; Seligman, 1975), it could be extrapolated to investigate whether people assign responsibility regarding the future state of the environment to themselves (internal attribution) or to external agents (God, international interests, the government, fate, etc.), based on the assumption that an individual guides their proenvironmental actions depending on whether they consider a situation to be their responsibility or others'.

As a consequence, the principal aim of this study is to investigate the personal assessments made by the inhabitants of Latin American countries about environmental quality at a local, regional and global level, along with their level of optimism about future environmental conditions 
and the assignment of responsibility to different agents for its conservation. The implications of the findings for the formulation of environmental policies in the region are also discussed.

\section{Method}

\section{Participants}

A total of 944 people from eight Latin American countries were interviewed, chosen by means of nonprobability sampling, with each country providing between 96 and 120 participants, except Argentina, which accounted for a larger sample. Table 1 shows that the gender and age distribution of the participants was similar and balanced in all countries, again with the exception of Argentina, where more women responded to the survey, and fewer people aged 51 and over were interviewed. The participants' level of education was distributed evenly in the majority of countries, except in Colombia, where a higher number of people had a secondary level of education, and in Argentina, where almost all the participants were university students.

\section{Design}

A transectional correlational descriptive study was carried out, comparing eight data sets corresponding to the participating countries.

\section{Instruments}

A survey was applied with 22 items related to the environmental perception of citizens in Latin America. Each item was evaluated by the respondent at a local, national and global level. The items and the measurement scales were adapted from the instrument used by Gifford et al. (2009) in an environmental perception study in different countries from around the world, in which only Mexico and Brazil featured as representatives of Latin America. For each item, the participants rated the current state of the environment, using a scale ranging from 1 (very bad) to 5 (very good). They then had to judge the future state of each environmental aspect using a scale ranging from -2 (much worse) to 2 (much better). An additional evaluation scale was included so that the participants could determine which person/people or entities were responsible for each of the environmental problems. This additional scale was derived from the study by Barros, Pinheiro and Gunther (2010).

The items were translated into Spanish and Portuguese, and two additional items were included to reflect problems that are specific to the region such as mining and oil pipelines. A pilot test was carried out for this instrument with 40 people in Bogotá (Colombia). Within this pilot test, a content validation was conducted for each of the items with a view to ensuring that the participants understood

TABLE 1. Demographic distribution of the sample

\begin{tabular}{|c|c|c|c|c|c|c|c|c|c|c|}
\hline \multirow[b]{2}{*}{ Country } & \multicolumn{4}{|c|}{ Age } & \multicolumn{2}{|c|}{ Gender } & \multicolumn{3}{|c|}{ Level of Education } & \multirow[b]{2}{*}{ Total } \\
\hline & $\begin{array}{c}17-23 \\
\text { years old }\end{array}$ & $\begin{array}{c}24-35 \\
\text { years old }\end{array}$ & $\begin{array}{c}36-50 \\
\text { years old }\end{array}$ & $\begin{array}{l}51 \text { or } \\
\text { over }\end{array}$ & Female & Male & Primary & Secondary & University & \\
\hline Colombia & 42 & 31 & 21 & 23 & 54 & 63 & 34 & 66 & 17 & 117 \\
\hline Venezuela & 28 & 27 & 31 & 29 & 57 & 58 & 37 & 39 & 39 & 115 \\
\hline Brazil & 30 & 32 & 29 & 29 & 60 & 60 & 40 & 40 & 40 & 120 \\
\hline Argentina & 78 & 75 & 16 & 6 & 119 & 56 & 0 & 9 & 166 & 175 \\
\hline Chile & 24 & 19 & 26 & 27 & 52 & 44 & 38 & 26 & 32 & 96 \\
\hline Mexico & 30 & 26 & 25 & 31 & 51 & 61 & 35 & 39 & 38 & 112 \\
\hline Costa Rica & 27 & 27 & 30 & 28 & 57 & 55 & 34 & 39 & 39 & 112 \\
\hline Peru & 16 & 22 & 34 & 25 & 54 & 43 & 21 & 48 & 28 & 97 \\
\hline Total & 275 & 259 & 212 & 197 & 504 & 440 & 239 & 306 & 399 & 944 \\
\hline
\end{tabular}

Source: own work 
the content of the item and the evaluation scale. Any items where the wording might cause confusion were adjusted, and the response option "don't know" was included for cases in which the participants understood the question but did not have the information required to form a judgement. In addition, the questionnaire was sent to three expert judges, psychologist experts in psychometrics, who approved it fully before application. In general, the instrument obtained a high level of reliability, with a Cronbach alpha coefficient of 0.98 , an almost identical value to that obtained by Gifford et al. (2009).

\section{Procedure}

In each of the countries included in the study, leading experts in Psychology who were also members of research groups were contacted to coordinate the application of the surveys. Each country was responsible for collecting and digitalising data. To this end, each of the teams was sent the possible composition of the sample, the form and the digitalisation matrix. All the matrices were subsequently integrated into the same database in order to analyse the total sample. A Free and Informed Consent was obtained from respondents in each Latin American country. In addition the application of the questionnaire was completely anonymous.

\section{Results}

\section{Country Averages}

In order to compare the mean values obtained for each country in relation to the factors considered in the instrument, the mean items measuring the perception of the state of the environment in the present and future at the local, national and global levels were averaged (see figure 1). The average values considered all the countries in the sample with the exception of Brazil, given that its mean values were significantly higher in each of the aspects and levels evaluated, as shown in Table 2 and Figure 2.

Table 2 shows the distribution of mean values by country, and Figure 2 shows the apparent differences between them. There is a similar perception about the environment in Latin American

Figure 1. Average perception of the state of the environment in Latin American countries

Source: own work

\begin{tabular}{|l|l|l|l|l|}
\hline Universitas Psychologica & V. 14 & No. 2 & abril-junio | \\
\hline
\end{tabular} 
countries. Clearly, Brazil is more optimistic about the environment in comparison with other Latin American countries. Furthermore, Chile seems to be the most pessimistic country in relation to the environment, for most aspects, closely followed by Costa Rica and Argentina. Greater pessimism is observed in general in relation to the environment at a global level, both in the present and the future, but unlike in previous studies such as that of Gifford et al. (2009), the average perception of the local environment is very similar to that of the national and the global environment.

\section{Perception of the State of the Environment}

In relation to each of these average vales, the countries were compared using a single-factor ANOVA and a post-test to determine the differences between the countries. Significant differences were observed between the countries in their perception of the state of the environment at a local level ( $F(7.369)$ $=28.314, p=0.00)$. Since the variances were not equal, as shown by Levene's test of homogeneity, it was necessary to apply a post-hoc-test appropriate to this characteristic: the Games-Howell test was administered, comparing each country with the others, and establishing their differences between the mean values and each of the countries, as well as the direction and significance of the differences. This procedure was followed for all comparisons. In the specific case of the local present factor, Brazil displayed higher average values than the other Latin American countries, signifying greater optimism with regard to the state of the environment in the local area, specifically Sao Paulo. Although Chile displays less optimism than Brazil, it is still ahead of Venezuela, Argentina, Mexico and Peru.

\section{Estimation of the Present}

The aspects about which citizens are most optimistic in the present at the local level of the city where they live are drinkable water, biodiversity, soil quality and the built environment, whereas greater pessimism is felt at this level in relation to vehicular traffic. At a national level, the greatest optimism for the current situation relates to drinkable water, biodiversity, parks and green areas, forest and jungles, the built environment, and soil quality. Regarding the state of the environment in the world, in general the scores were lower and similar to one another for the aspects evaluated. Regarding future environmental estimations, a negative tendency was observed in almost all aspects (scores between zero and -1), with the exception of the built environment and natural disasters, with positive estimations at all levels.

Table 3 shows the different signs between the average values for the different countries, to identify cases in which the direction of the difference was significant. A positive sign (+) means that the country in the row possesses a significantly higher average than the country in the column.

TABLE 2. Mean values for the questionnaire subscales applied in each country

\begin{tabular}{lcccccccccccc}
\hline \multirow{2}{*}{ Country } & \multicolumn{2}{c}{ Local present } & \multicolumn{2}{c}{ Local future } & \multicolumn{2}{c}{ National present } & \multicolumn{2}{c}{ National future } & \multicolumn{2}{c}{ Global present } & \multicolumn{2}{c}{ Global future } \\
\cline { 2 - 13 } & Mean & SD & Mean & SD & Mean & SD & Mean & SD & Mean & SD & Mean & SD \\
\hline Colombia & 2.5864 & 0.50916 & -0.2527 & 0.61720 & 2.6729 & 0.44329 & -0.3095 & 0.67362 & 2.6552 & 0.47997 & -0.3680 & 0.73738 \\
\hline Venezuela & 2.3202 & 0.42337 & -0.2173 & 0.86157 & 2.3052 & 0.48024 & -0.2616 & 0.90456 & 2.5498 & 0.72091 & -0.1636 & 0.97269 \\
\hline Brazil & 3.3947 & 0.89735 & 1.4768 & 1.49194 & 3.2097 & 0.98733 & 1.3549 & 1.57501 & 3.8677 & 1.58986 & 1.9091 & 2.07065 \\
\hline Argentina & 2.3049 & 0.47075 & -0.5201 & 0.77343 & 2.4905 & 0.58413 & -0.5974 & 0.66836 & 2.3307 & 0.64167 & -0.7143 & 0.73849 \\
\hline Chile & 2.8147 & 0.32802 & -0.9924 & 0.72123 & 2.6077 & 0.40464 & -0.9711 & 0.63189 & 2.3712 & 0.66064 & -1.1970 & 0.39756 \\
\hline Mexico & 2.4165 & 0.55705 & -0.6364 & 0.67329 & 2.4485 & 0.52678 & -0.6286 & 0.61300 & 2.4906 & 0.61395 & -0.6427 & 0.61214 \\
\hline Costa Rica & 2.4058 & 0.65129 & -0.5714 & 1.02367 & 2.4091 & 0.64191 & -0.5509 & 1.04152 & 2.0336 & 0.54429 & -0.7348 & 1.08626 \\
\hline Peru & 2.3581 & 0.47065 & -0.3669 & 0.44300 & 2.3059 & 0.49608 & -0.3976 & 0.45745 & 2.2814 & 0.47815 & -0.4520 & 0.42287 \\
\hline Total & 2.7141 & 0.79253 & 0.1030 & 1.29634 & 2.6400 & 0.76361 & -0.0156 & 1.26522 & 2.7943 & 1.16460 & 0.1128 & 1.62149 \\
\hline
\end{tabular}

Source: own work 
A negative sign $(-)$ means that the country in the row possesses a significantly lower average than the country in the column. The same analysis was carried out when estimating the present and future state of the environment at the three levels: local, national and global.

Regarding the state of the environment at the country level, homogeneity of variances in the responses is observed among the different populations interviewed (non-significant Levene test, $p=0.242$ ). In relation to this factor, significant differences are found between the average scores for the different countries $(F(7.432)=18.201, \mathrm{p}<0.05)$. As with environmental perceptions at the local level, Brazil displays higher average values than the other countries. Furthermore, Colombia is ahead of Venezuela and Peru regarding environmental perceptions at a national level.

Significant differences are also observed in the average scores for the different countries regarding estimations of the state of the environment in the world. An $(F(7.415)=28.642, p=0.00)$ was obtained, with non-homogeneous variances. The post-test established that Brazil displays higher average values than the other Latin American countries regarding perceptions of the state of the environment in the world. Colombia is also more optimistic on this point than Costa Rica and Peru, and Mexico is more optimistic than Costa Rica, which yielded lower average scores (see Table 3).

\section{Estimation of the Future}

As for optimism or pessimism regarding the future state of the environment, within the local sphere of the city where the instruments were applied, significant differences were observed between the different countries $(F(7.353)=40.320, p=0.00)$. The same was noted for perceptions regarding the future of the environment at a national level, where significant differences were observed between the different countries $(F(7.412)=39.249, p=0.00)$. Since the variances were not equal, the post-test was applied, finding that Brazil displayed the highest average values compared with the other countries included in the sample, showing greater optimism regarding the

Figure 2. Average scores for current environmental conditions and estimated future conditions at the local, national and global level for each country.

Source: own work 
TABLE 3. Difference signs between countries denoting environmental perceptions in the present.

\begin{tabular}{|c|c|c|c|c|c|c|c|c|}
\hline Country & Level & Col & Ven & Arg & Chil & Mex & Cost & Per \\
\hline \multirow{3}{*}{ Colombia } & Local & & & & & & & \\
\hline & National & & $+(\mathrm{p}=0.007)$ & & & & & $+(\mathrm{p}=0.001)$ \\
\hline & Global & & & & & & $+(\mathrm{p}=0.001)$ & $+(\mathrm{p}=0.002)$ \\
\hline \multirow{3}{*}{ Venezuela } & Local & & & & $-(\mathrm{p}=0.003)$ & & & \\
\hline & National & $-(p=0.007)$ & & & & & & \\
\hline & Global & & & & & & $+(\mathrm{p}=0.02)$ & \\
\hline \multirow{3}{*}{ Argentina } & Local & & & & $-(p=0.01)$ & & & \\
\hline & National & & & & & & & \\
\hline & Global & & & & & & & \\
\hline \multirow{3}{*}{ Chile } & Local & & $+(\mathrm{p}=0.003)$ & $+(\mathrm{p}=0.01)$ & & $+(\mathrm{p}=0.05)$ & & $+(\mathrm{p}=0.005)$ \\
\hline & National & & & & & & & \\
\hline & Global & & & & & & & \\
\hline \multirow{3}{*}{ México } & Local & & & & $-(p=0.05)$ & & & \\
\hline & National & & & & & & & \\
\hline & Global & & & & & & $+(\mathrm{p}=0.04)$ & \\
\hline \multirow{3}{*}{ Costa rica } & Local & & & & & & & \\
\hline & National & & & & & & & \\
\hline & Global & $-(p=0.001)$ & $-(p=0.02)$ & & & $-(p=0.04)$ & & \\
\hline \multirow{3}{*}{ Peru } & Local & & & & $-(p=0.005)$ & & & \\
\hline & National & & & & & & & \\
\hline & Global & $-(p=0.002)$ & & & & & & \\
\hline \multirow{3}{*}{ Brazil } & Local & $+(\mathrm{p}=0.000)$ & $+(\mathrm{p}=0.000)$ & $+(\mathrm{p}=0.000)$ & $+(\mathrm{p}=0.001)$ & $+(\mathrm{p}=0.000)$ & $+(\mathrm{p}=0.001)$ & $+(\mathrm{p}=0.000)$ \\
\hline & National & $+(\mathrm{p}=0.000)$ & $+(\mathrm{p}=0.000)$ & $+(\mathrm{p}=0.000)$ & $+(p=0.000)$ & $+(\mathrm{p}=0.000)$ & $+(\mathrm{p}=0.000)$ & $+(\mathrm{p}=0.000)$ \\
\hline & Global & $+(\mathrm{p}=0.000)$ & $+(\mathrm{p}=0.000)$ & $+(\mathrm{p}=0.000)$ & $+(\mathrm{p}=0.000)$ & $+(\mathrm{p}=0.000)$ & $+(\mathrm{p}=0.000)$ & $+(\mathrm{p}=0.000)$ \\
\hline
\end{tabular}

Source: own work

future state of the environment in Sao Paulo and also in relation to the country as a whole. In the other countries, there are no significant differences in the estimations given for the local or national future. As with the estimation of the city's environmental future, no significant differences were found in the average scores comparing each country with the others (see Table 4).

Analysing the optimism or pessimism regarding the future state of the environment at a global level, significant differences were observed between the different countries $(F(7.399)=45.079$, $p=0.00$ ). Since the variances were not equal, the post-test was applied to establish the differences between the specific averages obtained for each country. Brazil yields higher average scores than the other Latin American countries. Venezuela, Peru and Colombia display a higher degree of optimism than Chile.

\section{Responsibility}

For each of the items, the participants evaluated the contribution made by different social agents to the environmental issue. In general, with the exception of Brazil, participants from the different countries assigned a high level of responsibility to external social agents at the different levels, increasing their judgement of external responsibilities at the national and global levels of analysis. The majority attribute greater responsibility to citizens with regard to local environmental problems. At a local level, the respondents assign greater responsibility to the general population in relation to environmental issues, with the exception of: oil wells and pipelines, mine exploitation, waste management, drinkable water, and radioactive waste. They assign responsibility to the general population with regard to: noise management, size of the human 
TABLE 4. Plus/minus signs between countries regarding future estimations of the state of the environment.

\begin{tabular}{|c|c|c|c|c|c|c|c|c|}
\hline Country & Level & $\mathrm{Col}$ & Ven & Arg & Chil & Mex & Cost & Per \\
\hline \multirow{3}{*}{ Colombia } & Local & & & & & & & \\
\hline & National & & & & & & & \\
\hline & Global & & & & $+(\mathrm{p}=0.002)$ & & & \\
\hline \multirow{3}{*}{ Venezuela } & Local & & & & & & & \\
\hline & National & & & & & & & \\
\hline & Global & & & $+(\mathrm{p}=0.05)$ & $+(\mathrm{p}=0.000)$ & & & \\
\hline \multirow{3}{*}{ Argentina } & Local & & & & & & & \\
\hline & National & & & & & & & \\
\hline & Global & & $-(p=0.05)$ & & & & & \\
\hline \multirow{3}{*}{ Chile } & Local & & & & & & & \\
\hline & National & & & & & & & \\
\hline & Global & $-(p=0.002)$ & $-(p=0.000)$ & & & & & $-(\mathrm{p}=0.005)$ \\
\hline \multirow{3}{*}{ Mexico } & Local & & & & & & & \\
\hline & National & & & & & & & \\
\hline & Global & & & & & & & \\
\hline \multirow{3}{*}{ Costa rica } & Local & & & & & & & \\
\hline & National & & & & & & & \\
\hline & Global & & & & & & & \\
\hline \multirow{3}{*}{ Peru } & Local & & & & & & & \\
\hline & National & & & & & & & \\
\hline & Global & & & & $+(\mathrm{p}=0.005)$ & & & \\
\hline \multirow{3}{*}{ Brazil } & Local & $+(\mathrm{p}=0.000)$ & $+(\mathrm{p}=0.000)$ & $+(\mathrm{p}=0.000)$ & $+(\mathrm{p}=0.001)$ & $+(\mathrm{p}=0.000)$ & $+(\mathrm{p}=0.000)$ & $+(\mathrm{p}=0.000)$ \\
\hline & National & $+(\mathrm{p}=0.000)$ & $+(\mathrm{p}=0.000)$ & $+(\mathrm{p}=0.000)$ & $+(\mathrm{p}=0.000)$ & $+(\mathrm{p}=0.000)$ & $+(\mathrm{p}=0.000)$ & $+(\mathrm{p}=0.000)$ \\
\hline & Global & $+(\mathrm{p}=0.000)$ & $+(\mathrm{p}=0.000)$ & $+(\mathrm{p}=0.000)$ & $+(\mathrm{p}=0.000)$ & $+(\mathrm{p}=0.000)$ & $+(\mathrm{p}=0.000)$ & $+(\mathrm{p}=0.000)$ \\
\hline
\end{tabular}

Source: own work

population, vehicular traffic, air quality, biodiversity, and state of the rivers, lakes and seas. Few respondents assigned responsibility to other forces in the state of the local environment, just as few of them considered that the problem was within their personal control.

At a national level, the respondents assign greater responsibility to the government with regard to: oil wells and pipelines, exploitation of mines, drinkable water and radioactive waste. In contrast, they assign responsibility to the general population with regard to noise management, the size of the human population, vehicular traffic, air quality, biodiversity, and the state of the rivers, lakes and seas. A minimal percentage of people consider that they are responsible for the state of the environment. Furthermore, a very low percentage of respondents assign responsibility to supernatural forces. Finally, at a global level, inter- national agents become important in terms of the assignment of responsibility, with the exception of noise management, biodiversity, parks and green areas, the human population, and the state of rivers, lakes and seas.

In the case of Brazil, certain differences were observed in relation with the assignment of responsibility at the three levels of geographic estimation. In general, it was found that Brazilians attribute greater responsibility in local matters to the general population, unlike the other countries, which recognise international interests in local environmental issues. At the local level, an important role is also assigned to the government and, to a lesser extent, to the general population, especially with regard to the issue of natural disasters, parks and green areas, oil wells and pipelines, radioactive waste and waste management. 


\section{Discussion}

The results of this study show that Latin Americans, with the exception of Brazilians, are not very optimistic about the current or future conditions of the environment. The general average scores obtained for the current state of the environment at a local, national and global level are very similar across the countries. This is also observed in relation to future expectations about the environment.

As indicated previously, aspects at the local level about which greatest optimism was displayed by the citizens of Latin America are: drinkable water, biodiversity, soil quality, and the built environment, whereas they experience greater pessimism with regard to vehicular traffic. At a national level, the situation is very similar, but in addition people are optimistic with regard to parks and green areas, and also forests and jungles. It is important to note that in general people are largely pessimistic about the majority of environmental aspects when they think at the global level. In estimations regarding the future of the environment, there was a general negative trend, with improved estimations for the built environment and natural disasters.

The Brazilian participants displayed a clearly optimistic tendency when evaluating the state of the environment. Comparing the average scores obtained for Brazil in the study by Gifford et al. (2009), the data retrieved from this current study are relatively higher with regard to average scores for estimations of the current and future state of the environment at all levels and in all aspects evaluated. This might be due to important changes such as new strategies for environmental improvement, as well as the social and economic policies of Brazil in comparison with the region (Power, 2010) with increasing confidence index both internal and external investors (A.T. Kearney, 2015).

Hence, with the exception of Brazil, there are no major differences between the countries, which could mean that they share similar education patterns in relation to the state of the environment. In the case of Chile and Mexico, it is possible that information regarding the environment provided in education institutions and in the public domain is more detailed (Geo-Chile, 2010; SEMARNAT, 2012), on the basis of the programmes available to this end, or it might also be an idiosyncratic cultural issue.

Unlike the findings of other studies that evaluate perceptions of the state of the environment (Gifford et al., 2009), there are no major differences between the local, national and global levels in the estimations of current or future conditions. In general, the average scores indicate that public perception in relation to the environment is largely unoptimistic, both in the city where they live and in their country and the world as a whole. In relation to their vision of the future, no differences are observed in relation to the geographical level, in the local, national and global sphere, although there is still pessimism, and the assessments are in general negative. Pessimism in relation to environmental conditions seems to be a shared vision on a global scale, comparing the general findings of this study with those obtained by Gifford et al. (2009).

The average scores presented at each spatial level (local, national, global) did not show greater optimism in the local sphere than in the national or global sphere among any of the participating countries, except Chile. This could suggest that in Latin American countries, optimism does not depend on the citizen's spatial proximity to the environment, which calls into question the universality of the phenomenon. In addition, some studies in specific areas of environmental estimation, which take data from Latin American countries, show that there is greater concern in the region for issues related with the stability of the global climate, in comparison with other regions of the world. Hence, for example, whereas $65 \%$ of Latin American respondents are concerned about the global climate, the average in all the countries interviewed is 54\% (Pew Research Center, 2013).

As noted by Shultz et al. (2012), several studies have documented the trend towards spatial bias, but transcultural studies do not provide theoretical explanations for this effect. One possible theoretical concepts related with this phenomenon is the positive identity with the place. When "there is a serious environmental problem in a place with 
which an individual closely identifies, the person may have a tendency to discount this problem" (p. 4). Motivated social cognition also may be related to spatial bias because individuals tend to perceive more positive qualities than the average person. Some of the studies supporting these assumptions are those of Hugh-Jones and Madill (2009), Epley and Dunning (2000), Epley and Whitchurch (2008).

It could also be supposed, given the data about assignment of responsibility, that environmental education in countries of this region focuses more on pointing out the environmental issue than in resolving these situations, which could explain the lack of personal control they accept regarding the solution to problems and in general their pessimism towards the future. In accordance with the above, Uzzel (2004) measured the seriousness of seven environmental problems and the feelings of responsibility regarding the action that should be taken, to discover whether people are more concerned about problems at a global level or whether they only relate to their immediate local environment. The study discovered that problems are perceived to be more serious on larger scales, but that responsibility is felt more at a local level. In other words, people perceive global environmental problems to be highly problematic, but they do not feel responsible for their occurring. It is important to note that the low level of responsibility individuals are willing to accept with regard to environmental problems is a phenomenon underscored by the UN as being essential in terms of overcoming the global environmental issue (ONU, 2013) and requiring urgent intervention in different countries given that, although current environmental conditions are not the responsibility of a single agent, individual consumption and management of resources is one of the biggest contributors to certain issues.

In relation to personal responsibility, the results reflect a lower degree of responsibility at a personal level, and this gradually increases in relation to other close levels until it reaches the global population. The above can be viewed from two perspectives: one would show that others are thought to be more responsible than oneself; and the other considers that individual responsibility is less than the sum total of everyone's responsibility. In any case, it coincides with Uzzel (2000) in the sense that at a global level, control goes beyond the power of the individual; the feeling of responsibility related to environmental problems decreases through this distance, caused by feelings of helplessness.

The pessimism revealed in this study raises the question of whether it is a real estimation or a sociocultural construction, distanced from the events experienced by citizens on a daily basis. Without lapsing into a catastrophic vision of the world, it is nonetheless true that Latin America is facing various environmental problems that citizens know about through the media and formal education. Others are part of the problems faced daily by communities, and estimations provided are the result of direct experience. Although the region has made impressive progress at all levels over the past 20 years, there are still multiple problems in meeting the basic needs of people, and poverty, instead of diminishing, is remaining stable in different countries in the region. In the year 2013, the UN indicated that the economic crises affecting developed countries will affect developing economies significantly, and in this context, pessimism is somewhat more understandable. Equally, the strategies of multinational companies in the exploitation of natural resources in terms of mining and the cultivation of genetically modified crops are also powerful facts in relation to which citizens experience a low level of perceived control.

Hence, although pessimism could be completely explainable, and even though many environmental problems are not within the control of everyday citizens, it is important to salvage the commitment of individuals to the environment, since this involvement has profound implications for sustainable behaviour. In general, the identification that what we do does not have a significant impact on the environment heralds inaction or omission. In contrast, experiences of control in relation to the environment generate much more sustainable and powerful activities. Within the clinical field, this topic has been developed in depth traditionally within the framework of 
clinically relevant behaviour, in relation to the first findings about despair learned as a model of behavioural inhibition in cases of depression (Seligman, 1975). More recently, Ramos (2000) has established that cognitive perception of control, defined on the basis of predictability and controllability of events, is central to survival and is a manifestation of cognitive defences developed on the basis of symbolic elements produced by the process of socialisation in each culture. In this respect, "the cultural system functions as an instrument in the cognitive defence of control when faced with the uncertainty and randomness of natural and cultural events" (p.1). According to Ramos (2000), education is the determining factor when learning that process, providing a basic element for social and cultural change.

On the basis of the above, it is clear that experiencing a lack of control over the environmental situation could be counterproductive, bearing in mind that the impact of environmental measures passes through the action of multiple individuals whose behaviour produces results that affect the general population, in the terminology of Glenn (Glenn, 1991), such as macrocontingencies and metacontingencies. Hence, pessimism and the assignment of responsibility to third parties is a binomial that must be modified at an individual, social and cultural level; the state of the environment is assessed pessimistically if citizens are not shown how to exercise control over their environment and enjoy scarce political participation in the decisions that affect the environment, although it is possible that in general in Latin America social and economic conditions are related with low participation in different aspects of social life (politics, education, etc.). Since the Rio Summit, emphasis has been placed on the need for environmental education to involve different aspects of the social, political and economic life of communities, and that for this reason it cannot be restricted to school institutions.

Research results are important to countries in the region insofar as they provide an indicator of how much citizens know about the natural resources of their country, and their apprecia- tion of the state they are in. Furthermore, the instruments used to reflect participants' perceptions of these aspects could be used to evaluate the impact of the media, the monitoring of environmental and educational policies about the importance of the sustainable use of natural resources at a local, national and global level, and the responsibility citizens feel with regard to their rational use, taking into account the general reliability of the instruments and their positive correlation between dimensions for the present and future time scales.

It is worth pointing out that for future studies, it would be advisable to take geographical differences into account when evaluating attitudes towards the environment, since in this study only the attitudes of participants from certain cities were considered. With this point of reference, it is important to evaluate in this same respect the perceptions of citizens from other cities and the rural area to gain a complete overview of the specific environmental situation of each country. The question remains as to whether the differences observed between the participants countries and Brazil are due to the composition of the sample, the city where they were selected (Sao Paulo), or a radical difference in the optimism/pessimism of Brazilian citizens. Seemingly, the composition of the sample did little to affect environmental perception, the clear evidence of this being that there were no major differences between the sample from Argentina and the other countries, even when their structures differed. However, the only way to respond to this question would be to replicate the study with qualitatively identical samples from the different countries.

Finally, perception studies can be complemented with different measures of proenvironmental behaviour other than self-reporting, with a view to evaluating the effectiveness of measures in the discursive plane, pertaining to verbal control over human behaviour through the following of rules and the consequences of behaviour, a dimension on which the effectiveness of governmental intervention plans for the national and international case ultimately rests. 


\section{References}

Ajzen, I. (1991). The theory of planned behavior. Organizational Behavior and Human Decision Processes, 50, 179-211.

A.T. Kearney (2015). Connected risk: investing in a divergent world. Foreing Direct Investment Confidence Index. Recuperado en: https://www. atkearney.com/documents/10192/5797358/Con nected+Risks\%E2\%80\%94Investing +in +a +D ivergent+World.pdf/e45b9ffa-700b-445e-bb34e2dfff082009

Bamberg, S., \& Moser, G. (2007). Twenty years after Hines, Hungerford and Tomera: A new metaanalysis of psycho-social determinants of proenvironmental behaviour. Journal of Environmental Psychology, 27, 14-25.

Barros, H., Pinheiro, J., \& Günther, H. (2010, 27 june-2 july). Who is responsible for the (worsening of) environmental problems? Explorations of Brazilian data. IAPS 21 Conference, Abstracts of Presentations.

Berenguer, J., Corraliza, J. A., \& Martín, R. (2005). Rural-Urban Differences in Environmental Concern, Attitudes, and Actions. European Journal of Psychological Assessment, 21, 128-138.

Corral-Verdugo, V., Garcia-Cadena, C. H., \& Frías-Armenta, M. (2010). Psychological approaches to sustainability: Current trends in theory, research and practice. Environmental Science, Engineering and Technology. New York: Nova Science Publishers.

Daneshvary, N., Daneshvary, R., \& Schwe, R. K. (1998). Solid-waste recycling behavior and support for curbside textile recycling. Environment and Behavior, 30, 144-161.

Epley, N., \& Dunning, D. (2000). Feeling "holier than thou": Are self-serving assessments produced by errors in self or social prediction. Journal of Personality and Social Psychology, 79, 861-875.

Epley, N., \& Whitchurch, E. (2008). Mirror, mirror on the wall: Enhancement in selfrecognition. Personality and Social Psychology Bulletin, 34, 1159-1170.

Geo Chile (2010). Informe País. Estado del Medio Ambiente en Chile 2008. Santiago: Universidad de Chile, Instituto de Asuntos Públicos, Centro de Análisis de Políticas Públicas.
Gifford, R., Scannell, L., Kormos, C., Smolova, L., Biel, A., Boncu, S., .... Uzzell, D. (2009). Temporal pessimism and spatial optimism in environmental assessments: An 18-nation study. Journal of Environmental Psychology, 29, 1-12.

Gifford, R., \& Sussman, R. (2012). Environmental attitudes. In S. D. Clayton (Ed.), The Oxford Handbook of Environmental and Conservation Psychology (pp. 65-80). Oxford: Oxford University Press.

Giuliani, M. V., \& Scopelliti, M. (2009). Empirical research in environmental psychology: Past, present and future. Journal of Environmental Psychology, 29, 375-386.

Glenn, S. S. (1991). Contingencies and metacontingencies: Relations among behavioral, cultural, and biological evolution. In P. A. Lamal (Ed.), Behavioral analysis of societies and cultural practices (pp. 39-73). Washington, D.C.: Hemisphere Publishing.

Heider, F. (1958). The Psychology of Interpersonal Relations. New York: Wiley.

Hernández, B., Hidalgo, M. C., Salazar-Laplace, M. E., $\&$ Hess, S. (2007). Place attachment and place identity in natives and non-natives. Journal of Environmental Psychology, 27, 310-319.

Howell, S. E., \& Laska, S. B. (1992). The changing face of the environmental coalition: A research note. Environment and Behavior, 24, 134-144.

Hugh-Jones, S., \& Madill, A. (2009). The air's got to be far cleaner here: A discursive analysis of placeidentity threat. British Journal of Social Psychology, 48, 601-624.

Klineberg, S. L., McKeever, M., \& Rothenbach, B. (1998). Demographic predictors of environmental concern: It does make a difference how it's measured. Social Science Quarterly, 79, 734-753.

Meadows, D. H., Meadow, D. L., \& Randers, J. (1992). Más allá de los límites del crecimiento. Madrid: El País Aguilar.

O.N.U. (2013) World Economic Situation and Prospects 2013 - Update as of mid-2013. United Nations publication, Sales No. E.13.II.C.2.

Páramo, P., \& Gómez, F. (1997). Actitudes hacia el medio ambiente: Su medición a partir de la teoría de facetas. Revista Lationamericana de Psicología, 29(2), 246-266. 
Pew Research Center (2013). Climate Change and Financial Instability Seen as Top Global Threats. Retrieved from: http://www.pewglobal.org/files/2013/06/PewResearch-Center-Global-Attitudes-Project-GlobalThreats-Report-FINAL-June-24-20131.pdf.

Power, T. (2010) Optimism, Pessimism, and Coalitional Presidentialism: Debating the Institutional Design of Brazilian Democracy. Bulletin of Latin American Research, 29(1), 18-33.Ramos, I. (2000) Procesos simbólicos y percepción cognitiva de control. Gazeta de Antropología, 16.

Rauwald, K. S., \& Moore, C. F. (2002). Environmental attitudes as predictors of policy support across three countries. Environment and Behavior, 34, 709-739.

Rotter, J. B. (1954). Social Learning and Clinical Psychology. Englewood Cliffs, NJ: Prentice - Hall.

Seligman, M. E. (1975). Helplessness: On Depression, Development, and Death. San Francisco: W. H. Freeman.

SEMARNAT (2012) Compendio de Estadísticas Ambientales 2012. México: SEMARNAT. Retrieved from: http://app1.semarnat.gob.mx/dgeia/informe_12/ compendio/

Shen, J., \& Saijo, T. (2008). Reexamining the relations between socio-demografic characteristics and individual environmental concern: Evidence from Shangai data. Journal of Environmental Psychology, 28, $42-50$.
Schultz, P. W. (2000). A multinational perspective on the relation between Judeo-Christian religious beliefs and attitudes of environmental concern. Environment and Behavior, 32, 576-591.

Schultz, W., Milfont, T., Chance, R., Tronu, G., Luis, S., Ando, K., ... Gouveia, V. (2012). Cross-Cultural Evidence for Spatial Bias in Beliefs About the Severity of Environmental Problems. Environment and Behavior, 46(3) 267, 302.

Tikka, P., Kuitunen, M. T., \& Tynys, S. M. (2000). Effects of educational background on students' attitudes, activity levels, and knowledge concerning the environment. Journal of Environmental Education, 31, 12-19.

Uyeki, E. S., \& Holland, L. J. (2000). Diffusion of proenvironmental attitudes? American Behavioral Scientist, 43, 646-662.

Uzzell, D. L. (2000). The Psycho-Spatial Dimension to Global Environmental Problems. Journal of Environmental Psychology, 20(3), 307 - 318.

Uzzell, D. L. (2004). From local to global: A case of environmental hyperopia. Newsletter of the International Human Dimensions Programme on Global Environmental Change, 4, 6-7.

Xiao, C., \& Dunlap, R. E. ( 2007). Validating a Comprehensive Model of Enironmental Concern CrossNationally: A U.S Canadian Comparison. Social Science Quarterly, 88, 471-493. 